\title{
Mainstream disaster health as a policy priority: experiences from Chennai floods and a cross sectional study during disaster relief phase
}

\author{
Edmond Fernandes ${ }^{1}$, Homolata Borah ${ }^{2}$, Soumya Shetty $^{3}$
}

\author{
${ }^{1}$ Department of Community Medicine, Yenepoya Medical College, Yenepoya University and CEO, Center for Health \\ and Development, India \\ ${ }^{2}$ Research Scholar, Jawaharlal Nehru University, New Delhi, India \\ ${ }^{3}$ Biostatistician, Center for Health and Development (CHD), India
}

Received: 20 April 2016

Revised: 21 April 2016

Accepted: 14 May 2016

\author{
*Correspondence: \\ Dr. Edmond Fernandes, \\ E-mail: edmondvirgo@gmail.com
}

Copyright: () the author(s), publisher and licensee Medip Academy. This is an open-access article distributed under the terms of the Creative Commons Attribution Non-Commercial License, which permits unrestricted non-commercial use, distribution, and reproduction in any medium, provided the original work is properly cited.

\begin{abstract}
Background: The months leading to the end of 2015 exposed the pernicious compromise of India's flood protection mechanism and India's deep unpreparedness for addressing Disasters and humanitarian emergencies. Chennai was washed out by the annual northeast monsoon during the November-December months of 2015. More than 500 people lost their lives and more than 18 lakh people were displaced and over 22 lakh vehicles were damaged with economic losses ranging from US\$7-15 billion, going by popular media estimates.

Methods: A cross sectional study was carried out through a convenience sampling $n=400$ and subjects coming under different wards in Chennai municipal corporation were administered a questionnaire which was made exclusively for the Chennai floods. The subjects who participated in the study were belonging to the outreach area zones identified by Help Age Chennai Mobile Unit. Help Age India and Help Age Chennai identified in particular worst affected zones due to the floods and provided medical relief. The first author observations while responding to the floods have also been synced into the discussion.

Results: The floods in Chennai led to significant depression among the populace where $87.9 \%$ felt depressed (p value $<0.009)$. $332(83 \%)$ felt that Governmental help did not come, and it signals the massive collapse of the Government structure. Public drainage water got mixed with the clean water during the floods and remained that way without adequate chlorination in many areas and $88.2 \%$ felt it affected their health ( $\mathrm{p}$ value $<0.001$ ).

Conclusions: Great co-ordination needs to be brought and work integrated between the city corporation, public work department, slum clearance board, housing boards and development authority to be able to respond to any catastrophe.
\end{abstract}

Keywords: Chennai floods, Disaster resilience, DM act 2005, Help age India, Climate change

\section{INTRODUCTION}

The months leading to the end of 2015 exposed more than 500 people lost their lives and more than 18 lakh people were displaced and over 22 lakh vehicles were damaged with economic losses ranging from US\$7-15 billion, going by popular media estimates the pernicious compromise of India's flood protection mechanism and India's deep unpreparedness for addressing disasters and humanitarian emergencies. Chennai was washed out by the annual northeast monsoon during the NovemberDecember months of 2015. The floods right royally lead to large scale displacements, collapse of Government 
machinery and socio-economic disturbance. ${ }^{1}$ The public health structure during the floods was out of control and self-styled individuals played demi-Gods to offer help. Public water supplies, sewage system and power supply crumbled off and injected sufficient amount of fear for outbreak of diseases like diarrhoea and leptospirosis. Contaminated water furthered the possibility of deteriorating personal hygiene and increased the risk for diseases including bacillary dysentery.

Chennai is the capital of Tamil Nadu state which lies in the eastern coast of south India where 3 water sources rush through it, namely Adyar river, Cooum river and Buckingham canal. Within a century, the city has grown almost 8 times in population, having a total population of nearly 47 lakhs with a growth rate of $13 \%$ and density of 26903.

Rapid urbanization led to socio-economic growth and widened the gap of disparities. Migrant population and encroachment of water bodies as slums reduced the rain water passing capacity in the existing water ways. The disappearance of natural depression, green cover due to human induced development accumulating waste, poisoning the atmosphere and increasing flood risk.

\section{METHODS}

A cross sectional study was carried out through a convenience sampling $n=400$ and subjects coming under different wards in Chennai municipal corporation were administered a questionnaire which was made exclusively for the Chennai floods. The subjects who participated in the study were belonging to the outreach area zones identified by help age Chennai mobile unit. Help Age India and help age Chennai identified in particular worst affected zones due to the floods and provided medical relief. The first author observations while responding to the floods have also been synced into the discussion.

\section{RESULTS}

There are many causes that can be attributed to the buildup of the Chennai floods. Gupta A and Nair S mention that uncontrolled urban sprawl and loss of natural drainage increases flooding risk in Chennai. Urban lakes and river beds like that of Cooum are filled and encroached, canals are degraded and polluted. ${ }^{2}$

A survey was conducted in 1994 which pointed to waterway contamination and anaerobic digestion which led to sludge accumulation causing hydraulic difficulties. Drescher et al pointed out that city has only $855 \mathrm{~km}$ of storm drains against $2847 \mathrm{~km}$ of urban roads which points out to inadequacy of storm water drainage and maintenance insufficiency. ${ }^{10}$

In-spite of floods affecting the Indian geography year after year, there is no unified flood control implementing agency. During the floods, 345 people $(86.3 \%)$ felt their health was affected by the floods. Various reasons can be attributed to health going berserk during floods. People often get panicky and leave their belongings and flee the house during flood situations. Those on regular medication for hypertension, diabetes, chronic kidney diseases lose access to the stocks. Those who needed water from time to time, did not get it due to obvious logistic problems. Among the flood affected victims, $87.9 \%$ felt that water logging in their houses had an impact on their health, possibly psychological ( $p$ value<0.001). The floods in Chennai led to significant depression among the populace where $87.9 \%$ felt depressed ( $p$ value $<0.009$ ). Under-preparedness to avert such disasters and not having faced a crisis of this nature ever before in their lifetime has led to depression. The socio-economic losses and damage to property had left a lifetime scar on their minds which will take years to recover. Dr Noji argues that many reported morbidity problems caused by disasters including hypertension and cardiovascular disease - and even leukemia and lymphoma - may be stress-related by Noji. ${ }^{3}$

During floods, transportation gets affected severely. Until the waters recede, any form of movement other than aerial relief cannot be done. $329(82.3 \%)$ felt that they did not get relief material on time. India's disaster preparedness is by far very less. Absence of mock drills, absence of disaster readiness during no disaster time leads to severe chaos and confusion during disaster times. $332(83 \%)$ felt that Governmental help did not come, and it signals the massive collapse of the Government structure. The Tamil Nadu Chief Minister asked the Central Government to declare the Chennai floods as a National Calamity, which could be held true in many ways. $^{4}$ But it became a national calamity due to lack of political will, absence of urban risk mitigation plans and no public health emergency plan.

By and large, international NGOs exist who often rush to the spot during humanitarian emergencies. The relief they provide during such emergencies is enormous and helps save lives at large. $275(68.8 \%)$ felt they received external help from Non-Government organizations and private institutions. What kind of help is needed during what emergencies often depends upon the initial rapid assessment.

Clean and safe drinking water during floods remains by far a challenge to any administration. Chennai floods was no different. Media reports were doing the rounds and fear of disease outbreaks was very much palpable..$^{5}$

But even after post rains day 2, there were some areas where the waters did not recede. $333(83.3 \%)$ did not get clean and safe drinking water. Few NGO's provided for bottled water and the mightiest of the lot got the benefits of it. $356(89 \%)$ did not get clean water for shower and for sanitary needs, women among them suffer the most. Public drainage water got mixed with the clean water during the floods and remained that way without 
adequate chlorination in many areas and $88.2 \%$ felt it affected their health ( $\mathrm{p}$ value $<0.001$ ).

$267(66.8 \%)$ felt there were less doctors during floods. This lack of doctors points out to the intense shortage of healthcare personnel. Medical Council of India should see disaster response and disaster health as an immediate priority. Infact a fellowship in disaster health post MBBS recognized by Medical Council of India and by Ministry of Health and Family Welfare should be provided. ${ }^{6}$

Public transport gets paralyzed during floods and restoring it, requires lot of checks and balances. 343 $(85.8 \%)$ said there was no proper public transport during floods and afterwards. Much of the efforts need to be channelled towards efficient public transport recovery post floods.

Disaster works on the psychology of individuals and families get affected the most. 380 (95\%) felt that they were worried about the future of their family.

$361(90.3 \%)$ felt their house was damaged during floods and $309(77.3 \%)$ lost their children's education materials due to floods. Building resilience needs active community participation and in a more organized fashion. $303(75.8 \%)$ lost their government documents during floods and $374(93.5 \%)$ felt depressed after the floods. A cross sectional study done in New Zealand by Gowan M et al, said that it is important to orient people to take their Government documents while leaving their houses during floods so that the recovery and rehabilitation process becomes easier and faster. ${ }^{7}$

The mere fact that 303 people lost their Government documents during the Chennai floods points to the fact that India needs to improve its disaster literacy efforts in a very big way.

$373(93.3 \%)$ said that public drainage water entered their houses and got mixed with the clean water. 221 (55.3\%) said they had no form of insurance that they could get for the losses incurred by their families due to the floods. During the floods, flood waters in many areas did not recede and due to which in most parts there was darkness. $88.3 \%$ felt that their health was affected as there was no electricity and it was unusual for them to be without electricity on a natural course for completing their work, possibly leading to stress ( $\mathrm{p}$ value $<0.001$ ).

\section{DISCUSSION}

Floods are as such very common to Indian settings and a welcome realization took place in 2005 with the Disaster Management Act becoming an Act of Parliament. Much hasn't changed since then. The least civilians could hope for was the change in the attitude of those they elect to the hustings. It was established that the state Government did not follow the standard operating procedure to mobilize the police for relief and rescue work. About 1.15lakh strong police force remained near idle for a fortnight and the state was a place where paradoxes reigned supreme. 30,000 cops were left idle at the time of the disaster taking place, as claimed by the report published by The Times of India. ${ }^{8}$

Government apathy calls for serious introspection and reflection in the minds of civilians. Disasters teach civilians one lesson, how to carefully elect and select the leadership. Floods occurring are a natural phenomenon to India, but for Chennai to be flooded to this magnitude was a model of self-destruction by mankind. Human interventions and activity at the river beds of the Couum River and alternations arising of the drainage pattern due to compromised urban priorities, quick money, and deforestation have pushed civilians to the brink and have permanently scarred the river basins.

Risk and vulnerability assessment in metro cities and fast growing tier II cities are existing on a knee jerk basis. Disasters bring out the best of humanity and also at times the worst of humanity. Exploitation, care, love everything gets mixed. During one of the medical camps, a local politician came along, took photos and walked away, only to draw mileage from someone else's effort. No sense of guilt, shame or remorse existed. Such activities should be checked and action must be taken by local communities.

Chennai floods are a classical case of not prioritizing Disaster mitigation and resilience in no disaster time. National efforts to restore rivers' natural flood prone zones must be intensified and enhanced so that flood plains can retain water and flood impacts can significantly be alleviated. According to Intergovernmental Panel on Climate Change (IPCC), sea level is expected to rise around $9 \mathrm{cms}$ to $88 \mathrm{cms}$ by the year 2100 and the earth will warmer by 1.4 to 5.8 degrees Celsius. ${ }^{9}$

Flood protection mechanism and disaster resilience efforts needs to build up in more meaningful ways so that co-ordinated standard operating procedures can be followed in the given local region affected by disasters. It was noted that Chennai flood response lacked a proper public health response plan. Doctors were hopping in from different quarters to offer their services but they did not know under which umbrella to work and how to work.

International NGO's responding to the floods did not have appropriate military or police protection while giving away food packets and during health camps and measures to provide for security detail to ground level organizations remains imperative. It is by far very clear that the Chennai flood response was a reactionary response in need of salvation, but what we need and what lessons we need to know is we have had enough on paper and its long overdue to exercise practicality of the same. 


\section{CONCLUSION}

Great co-ordination needs to be brought and work integrated between the city corporation, public work department, slum clearance board, housing boards and development authority to be able to respond to any catastrophe. Health during disasters needs to be mainstreamed and adequate stock of medical drugs supplies needs to be kept. Disaster literacy and mock drills in no disaster times should be stepped up and seen as a much needed mandate. The disaster management act 2005 must be revisited and amendments are needed to incorporate Public health dimensions to the act. Perhaps, can we think of a basic law of national resilience 2016?

\section{ACKNOWLEDGEMENTS}

Authors would like to thank Help Age India for the response to Chennai floods and also Dr. M Vijayakumar, Hon'ble Vice Chancellor, Yenepoya University and Dr. Abhay Nirgude, Professor and Head, Department of Community Medicine, Yenepoya Medical College for facilitating the response.

Funding: No funding sources Conflict of interest: None declared

Ethical approval: Not required

\section{REFERENCES}

1. Chennai Floods. 2015. Available at:https://en.wikipedia.org/wiki/2015_South_Indian _floods (Accessed: 5th April, 2016).

2. Gupta K, Nair S. Flood risk and context of landuses: Chennai city case. Journal of Geography and Regional Planning. 2010;3(12):365-72.

3. Noji E. The Public Health Consequences of Disasters. New York. Oxford University Press. 1997.

4. Janardhanan A. Declare Chennai floods national calamity, Jayalalithaa urges PM Modi. 2015. Available at: http://indianexpress.com/ article/ india/india-news-india/ jayalalithaa-urges-pm-modito-declare-chennai-floods-as-national-calamity/ (Accessed: 5th April, 2016).

5. Hamid Z. Fear over disease outbreak allayed. 2015 Availableat:http://www.thehindu.com/ news/ cities/ chennai/ fear-over-disease-outbreak allayed/ article7993984.ece (Accessed: 5th April, 2016).

6. Fernandes E, Borah H. Lessons from Humanitarian Emergencies. 2016. Available at: http://www.financialexpress.com/ article/ healthcare/ strategy/ lessons-from-humanitarianemergencies/ 209115/ (Accessed: 5th April, 2016).

7. Gowan M, Kirk R, Sloan J. Building resiliency: a cross-sectional study examining relationships among health-related quality of life, well-being, and disaster preparedness. Health and Quality of Life Outcomes. 2014;12:85.

8. TNN. Tamil Nadu govt let 30,000 cops sit idle while Chennai sank', The Times of India, Available online: http://timesofindia.indiatimes.com/ city/ chennai/ Tamil-Nadu-govt-let-30000-cops-sit-idlewhile-Chennai-sank/ articleshow/ 50084450.cms. Last Accessed : 21st April, 2016.

9. EU Report. Best practices on flood prevention, protection and mitigation. Available online: http://ec.europa.eu/environment/water/flood_risk/pd f/flooding_bestpractice.pdf. Last Accessed on 21st April, 2016.

10. Drescher A, Glaser R, Pfeiffer C, Vencatesan J, Schliermann-Kraus E, Glaser $\mathrm{S}$, et al. Risk assessment of extreme precipitation in the coastal areas of Chennai as an element of catastrophe prevention. Forum DKKV/CEDIM: Disaster Reduction in Climate Change 15./16.10.2007, Karlsruhe University, Germany.

Cite this article as: Fernandes E, Borah $\mathrm{H}$, Shetty S. Mainstream disaster health as a policy priority: experiences from Chennai floods and a cross sectional study during disaster relief phase. Int J Community Med Public Health 2016;3:1589-92. 